\title{
MAGELLAN PEAT (Sphagnum magallanicum) AS NATURAL ADSORBENT OF RECALCITRAN SYNTHETIC DYES.
}

\author{
Luisa A. Sepúlveda-Cuevas, Elsa G. Contreras-Villacura and Carolyn L. Palma-Toloza \\ Chemical Engineering Department - Universidad de Santiago de Chile \\ Av. Bernardo O’Higgins 3363 - Estación Central -Santiago -Chile. \\ Corresponding author: cpalma@usach.cl
}

\section{Turba magallánica (Sphagnum magallanicum) como adsorbente natural de colorantes sintéticos recalcitrantes}

Key words: adsorption, dyes, textile effluents.

\begin{abstract}
Colour abatement is a complex problem because the synthetic origin of the dyes used in the industry. The purpose of this study is to evaluate the feasibility of using Magellan peat (Sphagnum magallanicum) as an adsorbent of textile dyes, determining the physicalchemical characteristics of the peat by measuring the adsorptive capacity of the dyes as well as exploring the degrading potential of the native microorganisms they contain. The results obtained indicate that the peat has a specific surface area (BET) and a volume of $144.3 \mathrm{~m}^{2} \mathrm{~g}^{-1}$ and $60 \%$ of meso- and macropores, respectively. The basicity of the peat surface is superior to acidity and the $\mathrm{pH}$ in which the neutrality is reached is about 3.1. Equilibrium concentrations for the basic, acid and reactive dyes in the solid and liquid phases were appropriately interpreted by the Langmuir model; however the maximum adsorption capacities of the first ones were significantly higher. If the solution $\mathrm{pH}$ is lower to $\mathrm{p}_{z p c}$, the absorption capacity of the acid dyes increases. Three different bacteria colonies with decolourization capacity were isolated. In conclusion, results indicate that the peat may be successfully applied in the detoxification of textile effluents.
\end{abstract}


Palabras clave: Adsorción, colorantes, efluentes textiles.

\section{RESUMEN}

El abatimiento del color es un problema complejo dado el origen sintético de los colorantes utilizados en la industria. El propósito del presente estudio es evaluar la viabilidad de utilizar turba magallánica (Sphagnum magallanicum) como adsorbente de tintes textiles, determinando las características fisicoquímicas de la turba, evaluando la capacidad adsortiva de los tintes así como, explorando el potencial degradativo de los microorganismos nativos presentes en ella. Se determinó que la superficie específica (BET) y el volumen de meso y macroporos de la turba es de $144,3 \mathrm{~m}^{2} \mathrm{~g}^{-1}$ y $60 \%$, respectivamente. La basicidad de la superficie es superior a la acidez y el $\mathrm{pH}$ en el cual se logra la neutralidad es 3,1 . Las concentraciones de equilibrio de los tintes básicos, ácidos y reactivos en la fase sólida y líquida fueron apropiadamente interpretadas por el modelo de Langmuir, no obstante las capacidades máximas de adsorción de los primeros fueron superiores. Si el pH de la solución es inferior a pzpc la capacidad de adsorción de los tintes ácidos se incrementa. Se aislaron tres diferentes colonias de bacterias las cuales mostraron capacidad decolorativa. Estos resultados indican que la turba puede ser aplicada exitosamente en la detoxificación de efluentes textiles.

\section{INTRODUCTION}

Discharges of coloured effluents interfere with the photosynthetic processes in the receiving flows, reducing therefore the environment's assimilative capacity. Colour abatement, however, is a complex problem since the synthetic origin of the dyes used in the industry makes them refractory to conventional treatments. Different alternative treatments have been explored to minimize contamination of ecosystems by the release of this type of coloured compounds produced by the most varied industrial sectors, including the textile industry. This process help decolourization only by removing the dyes from the liquid phase or otherwise, by degrading, and even, mineralizing this kind of organic molecules that are present. It is because of this reason that the most recent technologies are based on a hybrid process, i.e., different combinations of physical, chemical and biological processes. Wastewaer arising from textile processes, particularly from dyeing baths, contains a mixture of dyes; therefore the application of these hybrid technologies may be more effective than individual treatments. Based on this hypothesis, a strategy is stated that considers a first adsorption phase in
Magellan Peat. Such physical-chemical operation would be a pre-treatment that, given the ability of the peat to adsorb and/or exchange cations, it would allow the transfer of dyes from a mixture, preferably those of the basic type. Degradation and/or mineralization of the carbon and nitrogen fraction of these coloured compounds present in each phase resulting from the adsorption process may subsequently be performed through biological treatment. Thus, for example, dyes that remain in the solution may be degraded by using microorganisms in a submerged or immobilized culture. In this proposal, an in vivo biological process is considered, using a continuous reactor with Phanerochaete chrysosporium, as immobilized biomass. At laboratory level, this white rot fungus has shown a capacity to degrade dyes, especially of the acid and reactive type, expressed by its extra-cellular enzymatic system as manganese peroxidase ( $\mathrm{MnP})$. Similarly, dyes that are adsorbed by the peat could be degraded though biologic processes over solid substrate in vivo or in vitro. Since peat is an organic matter generated by the decomposition of sphagnum-type mosses, it is colonized by a great diversity of 
microorganisms. It is thus possible to state that some of these native colonies have ligninolytic capacity and/or activity, which could be increased and used for the bioremediation of the adsorbent.

The application of dyes to the mixtures (whether acid, basic and reactive) of the proposed hybrid sequential process shows comparative advantages against individual processes, since two currents can be expected to result from this strategy: one liquid and one solid, the discharge and disposal of which, respectively, would have a minimum impact. The effluent would contain compounds of lower molecular weight, thereby reducing the colour and obtaining a waste current with a low organic load or at least capable of being treated with conventional processes. The solid detoxified waste could be finally used in energy applications or as soil fertilizer.

The purpose of this work is to characterize and evaluate Magellan peat (Sphagnum magallanicum) as a dye adsorbent for its use in a hybrid process of textile effluent treatment as well as to explore the degrading capacity of native microorganisms present in the adsorbent

\section{Adsorption: A pre-treatment technology}

The interest in having more economical adsorbents, which are relatively abundant and efficient in the removal of specific solutes, has encouraged the search of low-cost materials, among which those of natural origin such as the grape bagasse (McKay et al., 1987), rice bran (Sankar et al., 1999) and peat (Nawar and Doma, 1989) can be emphasized.

Particularly, peat, due to its vegetal origin, consists mainly of lignin and cellulose, and it also has a highly porous structure providing it a great characteristic surface area that permits its use as adsorbent. Several studies reported in the literature show satisfactory results regarding the adsorption of heavy metals on peat (Gosset et al., 1986, Ho et al., 1995, Ojeda et al., 1998, Ho and Mckay, 2000, Brown et al., 2000), pesticides such as 2,4-D (Cloutier et al., 1985) and dyes of different nature
(Allen et al., 1997, Mckay and Allen, 1980, Mckay et al., 1981, Ho and Mckay, 1998, Ho and Mckay, 1998, Contreras et al., 2000, Mckay et al., 2001).

\section{Native microorganisms in the peat: A bioremediation potential}

Bio-adsorbents have an additional advantage which is that the organic load that is adsorbed may be later treated though Solid Substrate Fermentation (SSF). Nigam et al., (2000) reported promissory results in the adsorption of dyes in some agricultural and forestry residues and the subsequent detoxification of the solid waste (adsorbent-dye) through SSF. The solid waste resulting from the adsorption and supplemented with ammonia nitrogen was an adequate substrate for growing white rot fungi Phanerochaete chrysosporium and Coriolus versicolor followed by the degradation of the absorbed dyes. The literature also reports results of bioremediation processes using bacteria that express an azoreductase activity. This is the case of Rhodobacter spheroidea, a bacterium that has been isolated from water systems and has shown a capacity to reduce xenobiotic nitro-aromatic compounds such as azoic dyes (Hong et al., 2005). Considering that peat is an organic material contained in microorganisms and is in the process of fossilization, it is possible to establish the presence of native colonies capable of biodegrade complex organic molecules such as dyes. Recently, a dyedecolourizing bacterium was isolated from a coconut coir sample. It aerobically decolourized different naphthalenecontaining sulfonated azo dyes. Orange II, Acid Red 151 and Acid Orange 12 were decolourized by $84 \%, 73 \%$ and $44 \%$, respectively in $24 \mathrm{~h}$. This bacterium required $0.5 \%$ of peptone, yeast extract and temperature of $38^{\circ} \mathrm{C}$ for growth. (Vijaykumar et al., 2007). High acidity, low temperature and extremely low concentration of the existing nutrients in the peatlands form an extreme habitat for 
microorganisms. Recent studies show that within the bacteria isolated from Sphagnum magellanicum peat that show an antagonist activity, the Burkholderia genre was the dominant group (Opelt et al., 2007). In any case the results of various investigations indicate that structure and activity of the microbial community will be strongly dependent on the type of peatland.

\section{MATERIALS AND METHODS}

Sphango type peat from the Magellan Region, Chile, was used in this study. It was conditioned, characterized and finally used in adsorption tests. The commercial product sold by ANASAC S.A. for agricultural purposes was directly used in order to isolate the microorganisms.

\section{Conditioning of the adsorbent}

Commercial peat has humidity levels between 60 and $80 \%$, so it was dried through a natural process on a $1 \mathrm{~cm}$-thick bed exposed to the air during a two-day period, and turning it every $5 \mathrm{~h}$.

\section{Characterization of the peat}

Particle size: The distribution of sizes of the commercial peat used in this process was determined through screening. Assuming a particle-size distribution in accordance with a distribution lognormal, Bennett's form of the Rosin-Rammler model (RRB) was used (Bennett, 1936). For later studies, the cut was selected between $[-18+60]$ meshes.

Density: Solid density was measured by liquid picnometry with hexane and gas picnometry with helium.

Specific surface: The specific surface was quantified with the Langmuir isotherm, using Methylene Blue (BB9). For this purpose, 12 samples were prepared with initial concentrations of 50 and $600 \mathrm{mg}$ $\mathrm{L}^{-1}$ of dye and a dose of $2 \mathrm{~g}$ of peat per solution litre, plus a blank consisting of distilled water and an equal dose of peat. These samples were continuously agitated in a thermostatized shaker at $30^{\circ} \mathrm{C}$ during a contact time of $24 \mathrm{~h}$. Finally, all samples were filtered determining the residual concentration of dyes in the solution by visible spectrophotometry. By way of comparison, the specific surface was determined through the BET isotherm with nitrogen. The distribution of pore sizes was evaluated through mercury porosimetry.

Acidity and basicity of the surface: This was determined by potentiometric titration with $\mathrm{HCl} 0.01 \mathrm{M}$ and $\mathrm{NaOH}$ $0.1 \mathrm{M}$ respectively, of a $20 \mathrm{~mL}$ aliquot of filtered solution obtained from contact assays for $24 \mathrm{~h}$ of $0.5 \mathrm{~g}$ peat with $50 \mathrm{~mL}$ of $\mathrm{NaOH} 0.01 \mathrm{M}$ (acidity) or $\mathrm{HCl} 0.1 \mathrm{M}$ (basicity), as the case may be.

Point of zero charge ( $\boldsymbol{p H} \boldsymbol{H}_{Z P C}$ ): This was determined by using 5 flasks with $1 \mathrm{~g}$ of peat, adding aliquots of 10, 7.5, 5, 2.5 and $1.25 \mathrm{~mL}$ of $\mathrm{HCl} 0.1 \mathrm{M}$ and other 5 with equal volumes of $\mathrm{NaOH} 0.1 \mathrm{M}$. Subsequently, all flasks were added with $5 \mathrm{~mL}$ of $\mathrm{KCl} 0.1 \mathrm{M}$ and distilled water was added up to a volume of $100 \mathrm{~mL}$, including a sample with only $\mathrm{KCl} 0.1$ $M$ and water. These samples were shaken for period of $1 \mathrm{~h}$, after which $\mathrm{pH}$ was measured for each sample $\left(\mathrm{pH}_{1}\right)$. To each sample were added $5 \mathrm{~mL}$ of $\mathrm{KCl} 1 \mathrm{M}$ again were shaken for period of $1 \mathrm{~h}$ and the $\mathrm{pH}$ of all them was measured $\left(\mathrm{pH}_{2}\right)$.

\section{Adsorption equilibrium: peat - dye}

In order to establish the affinity between different types of dye and the peat, the adsorption isotherms for Acid Black 1 (AB1), Basic Blue 3 (BB3), Basic Orange 2 (BO2), Basic Blue 24 (BB24), Basic Green 4 (BG4), Basic Violet 4 (BV4) were obtained, all of them of analytic quality. The reactive dyes Cibacron Yellow WR 200\% (RY), 
Cibacron Navy WB (RN), Cibacron Dark Blue WR (RB) and Cibacron Red WB $150 \%$ (RR), were also studied. These were supplied by Textil Jadue S.A.

Adsorption isotherm: The assays were performed in 125-mL Erlenmeyer flasks containing $0.4 \mathrm{~g}$ of peat (dry base) and $50 \mathrm{~mL}$ of dye solution, whose initial concentrations varied between 60 and $900 \mathrm{mg} \cdot \mathrm{L}^{-1}$. The mixture was shaken at $150 \mathrm{rpm}$ for $120 \mathrm{~h}$ at $30^{\circ} \mathrm{C}$. Colour measurement was made in a UV-Vis Helios-Gamma model spectrophotometer (Spectronic, UK). Absorbance values were registered at the corresponding wavelength of maximum absorption, as stated in Table 1 , using a filtered blank from an aqueous suspension obtained under the same conditions as the samples under study. Langmuir isotherm models were used to adjust experimental results. The model parameters were obtained through a regression analysis of minimum nonlinear squares.

Table 1: Maximum absorption wavelength of textile dyes

Cuadro 1: Longitud de onda de máxima absorción de los colorantes textiles

\begin{tabular}{lc}
\hline \multicolumn{1}{c}{ Dye } & $\boldsymbol{\lambda}(\mathbf{n m})$ \\
\hline Acid Black 1 (AB1) & 618.5 \\
Basic Blue 3 (BB3) & 654.5 \\
Basic Orange 2 (BO2) & 454.0 \\
Basic Blue 24 (BB24) & 633.0 \\
Basic Green 4 (BG4) & 615.5 \\
Basic Violet 4 (BV4) & 595.0 \\
Reactive Orange 16 (RO16) & 493.0 \\
Poly R-478 (PR478) & $520.0 / 350.0$ \\
Cibacron Yellow WR 200\% (RY) & 420.0 \\
Cibacron Dark Blue WR (RB) & 601.0 \\
Cibacron Navy WB (RN) & 598.0 \\
Cibacron Red WB 150\% (RR) & 506.0 \\
\hline
\end{tabular}

\section{Peat native microorganisms}

Bacterial strains were isolated from the wet peat and were classified according to their capacity to decolourize textile dyes. Dyes used were: Acid Black 1 (AB1), Basic Blue 3 (BB3), Reactive Orange 16 (RO16), Poly R-478, and the reactive dye Cibacron Red WB 150\% (RR).

Isolation of native microorganisms from Magellan Peat: In order to increase the growth of the different bacterial communities, $5 \mathrm{~g}$ of wet peat were added to a liquid medium supplemented with glucose and yeast extract, to which a fungal growth inhibitor was added ( $1 \%$ of Clotrimoxazol). The media were incubated at $37^{\circ} \mathrm{C}$ for $24 \mathrm{~h}$. Subsequently, $1 \mathrm{~mL}$ of medium was sowed in the solid media (agar-blood) using the groove sowing technique. The plates were incubated at $37^{\circ} \mathrm{C}$ for $24 \mathrm{~h}$. Each colony was identified and classified through the Gram's Stain method. 
Screening of bacteria isolated from Magellan Peat: With the colonies being isolated, the decolourizing assays were performed in a liquid medium, inoculating the growth medium supplemented with the dyes $\left(100 \mathrm{mg} \mathrm{L}^{-1}\right)$.

\section{RESULTSANDANALYSIS}

The peat used presented humidity between $70-75 \%$, which decreased up to $6.06 \pm 0.13 \%$ after finishing the drying process. The density of the selected cut was $1125 \mathrm{Kg}$ $\mathrm{m}^{-3}$; it was determined by liquid picnometry and corresponded to the range of particle sizes between 1 and $0.25 \mathrm{~mm}$. The distribution of their particle sizes is shown in Figures 1A. In this figure the mode corresponds to $0.725 \mathrm{~mm}$. On the other hand, the size distribution model of RosinRammler-Bennett (Figure 1B) adjusts quite well to the experimental data, with the estimated particle medium size value matching that determined from the frequency curve. The model parameters are informed in Table 2.
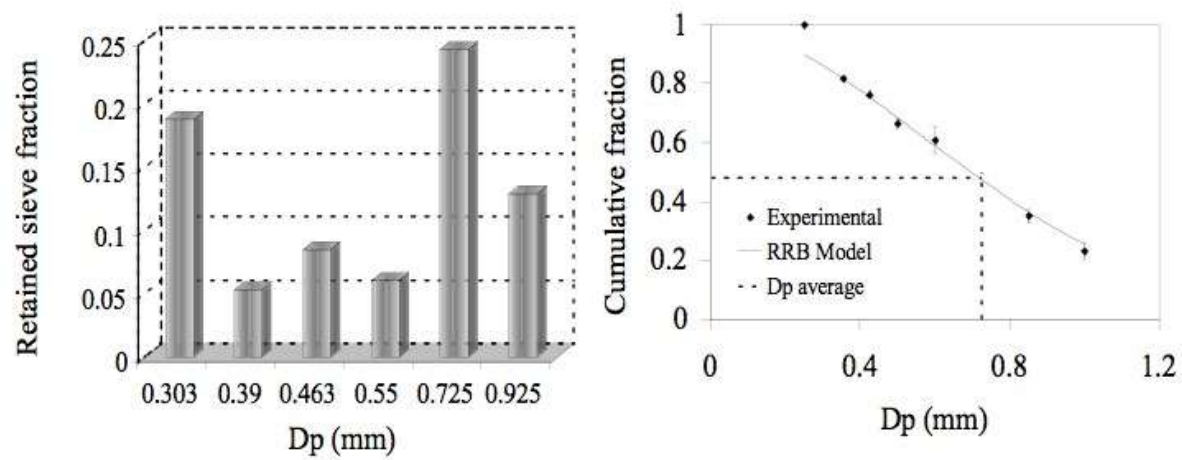

Figure 1: Distribution of the particle peat size

Figura 1: Distribución de tamaño de partícula de la turba

Table 2: RRB model parameters of the particle distribution size

Cuadro 2: Parámetros del modelo de RRB para la distribución de tamaño de partícula

\begin{tabular}{c|ccc}
\hline \multirow{2}{*}{$\boldsymbol{\varphi}=e^{-\left(X / X_{0}\right)^{n}}$} & $\mathbf{N}$ & $\mathbf{X o}$ & $\mathbf{R}^{\mathbf{2}}$ \\
\cline { 2 - 4 } & 1.906 & 0.829 & 0.996 \\
\hline
\end{tabular}


The surface area of the peat, quantified though the BET isotherm, is $144.3 \mathrm{~m}^{2} \mathrm{~g}^{-1}$, a value that is within the range obtained by other authors: from $27 \mathrm{~m}^{2} \mathrm{~g}^{-1}$ (Mckay and Allen, 1980) to $220 \mathrm{~m}^{2} \mathrm{~g}^{-1}$ (Cloutier, et al., 1985). If compared against activated carbon, which has a surface area between 300 and $1500 \mathrm{~m}^{2} \mathrm{~g}^{-1}$, the peat has the same order of magnitude than the lower limit (Knaebel, 1995). On the other hand, the Langmuir isotherm obtained for BB9 adsorption shows that the adsorption process indeed takes place in the dye monolayer over the adsorption surface. The specific peat surface area was obtained by adjusting the Langmuir isotherm for BB9, the parameters of which are shown in Table 3.

Table 3: Langmuir isotherm parameters

Cuadro 3: Parámetros de la isoterma de Langmuir

\begin{tabular}{cc}
\hline $\mathbf{K}_{\mathbf{L}}\left[\mathbf{L ~ g}^{-1}\right]$ & 36.538 \\
\hline $\mathbf{a}_{\mathbf{L}}\left[\mathbf{L} \mathbf{~ m g}^{-1}\right]$ & 0.164 \\
\hline
\end{tabular}

Considering that the surface covered by the molecule BB9 corresponds to $130 \AA^{2}$, the specific area surface is estimated at 545.2 $\mathrm{m}^{2} \mathrm{~g}^{-1}$, a higher value than that informed for an adsorbent prepared from an agricultural residue (Abia and Asuquo, 2006) According to the BET analysis, the medium pore radius of the peat is $25 \AA$, a characteristic value of the mesopore. Figure 2A shows the mercury intrusion curve permitting to quantify the volume of interconnected pores. It is observed that there is a limited intrusion value, a characteristic behaviour of a unimodal system. It is also observed that the greater contribution to the surface area of the peat under study corresponded to the micropores (pores having a size under $20 \AA$ ) equal to $40 \%$ of the total volume pores, a result that coincides with that reported in the bibliography (Cloutier, at al., 1985).

The incremental analysis of the intrusion curve led to obtain the distribution of pore size, identifying the characteristic sizes. This result shows that in the range of pore sizes between 4 and $1000 \AA$, the mode is located around $10 \AA$. The macropores defined with diameters above $500 \AA$ do not significantly contribute to the total surface area and represent $4 \%$ of the total pore volume, but they do allow channelling of the fluid towards the mesopores (which represent the remaining 54\%) and the micropores (Couillard, 1994). The morphology and size of the mesopores was characterized by electronic screening microscopy, as shown in Figure 2B, where the external channels are shown.

Determination of acidity in the peat surface was obtained after neutralization of the hydroxyl ions by the protons coming from the functional groups of the peat that become ionized in the solution (Figure 3A). The determination made by titrating excess $\mathrm{OH}^{-}$ions delivered a value of $0.89 \mathrm{mmol}$ $\mathrm{g}^{-1}$. Similarly, the basicity quantifies those functional groups in the surface that have non-binding electron pairs, than can interact with the protons present in the liquid phase. In this way, basicity is determined by the titration of $\mathrm{H}^{+}$ions that are still present in the solution after having reached the equilibrium condition (Figure 3B). The basicity obtained was $1.01 \mathrm{mmol} \mathrm{g}$. According to these results, the peat surface has a greater quantity of functional groups with non-binding electron pairs, since basicity is higher than acidity.

The tendency of the adsorbence surface to charge positively or negatively depends on concentration of protons in the solution. The $\mathrm{pH}$ value at which the load of the surface becomes void is called zero point charge $\left(\mathrm{pH}_{\mathrm{ZPC}}\right)$. Figure 4 shows that the $\mathrm{pH}_{\mathrm{ZPC}}$ value for the peat under study was 3.1. 


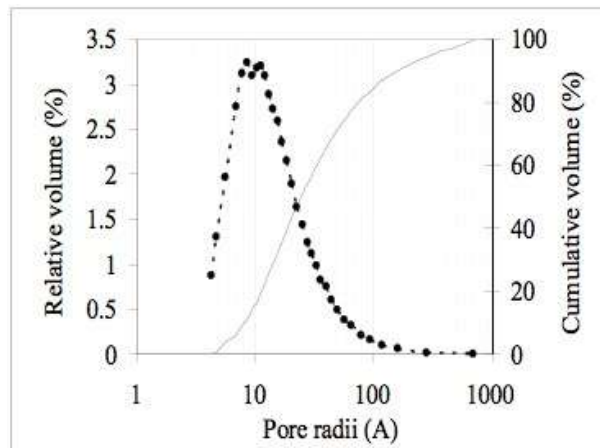

A: Distribution of pore size

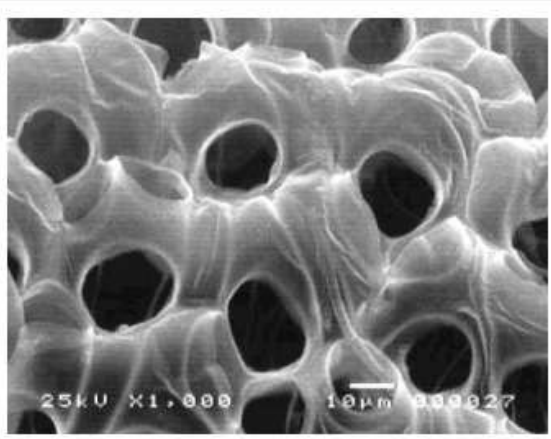

B: Microscopy of a peat screening scale 1:1000

Figure 2: Pore size distribution of peat

Figura 2: Distribución de tamaño de poro de la turba

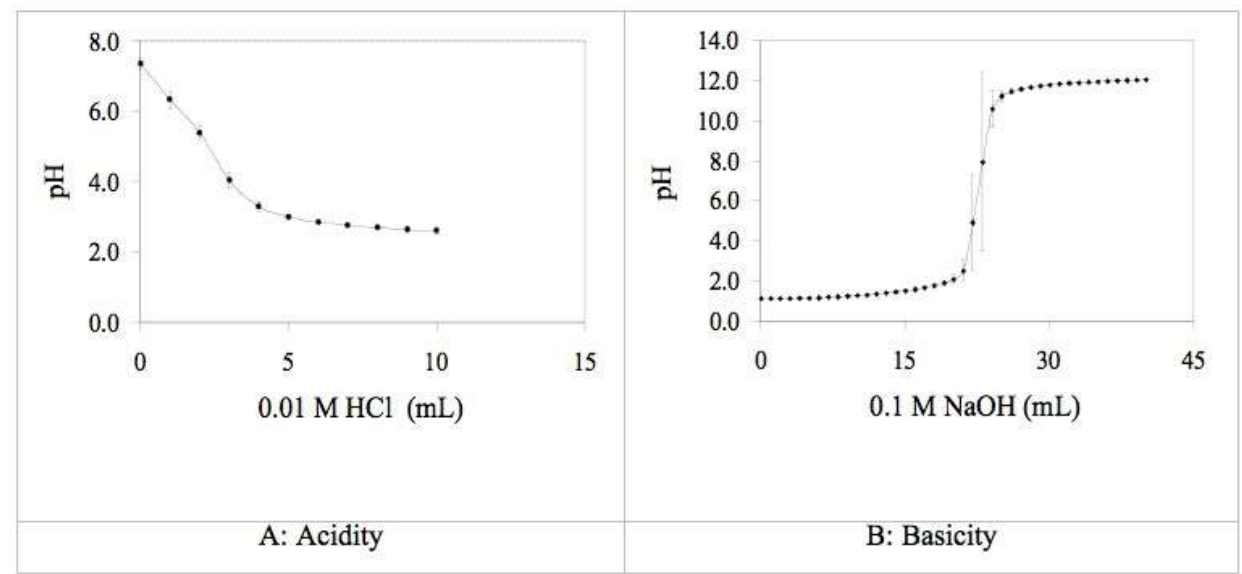

Figure 3: Surface acid-base properties of peat

Figura 3: Propiedades ácido - base de la superficie de la turba 


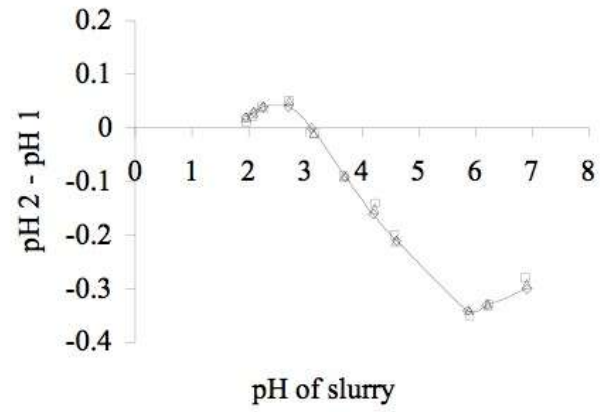

Figure 4: Point of zero charge of the peat

Figura 4: Punto de carga cero de la turba
Figure 5 shows the adsorption isotherms obtained for different dyes of the basic, acid and reactive type. In this figure, equilibrium concentrations were observed in the solid and liquid phase and were appropriately interpreted by the Langmuir model. Results stated that for basic and acid dyes (Figures $5 \mathrm{~A}$ and $5 \mathrm{~B}$ ) there is a slight impact of temperature on equilibrium, which indicates that the sorbate/adsorbent interaction is of chemical type (ionic exchange).
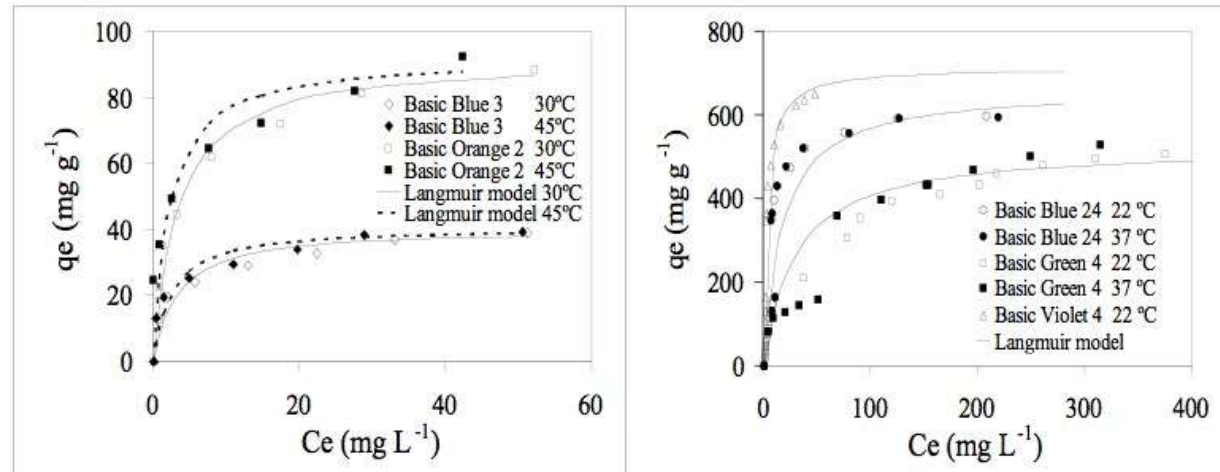

A: Basic dyes

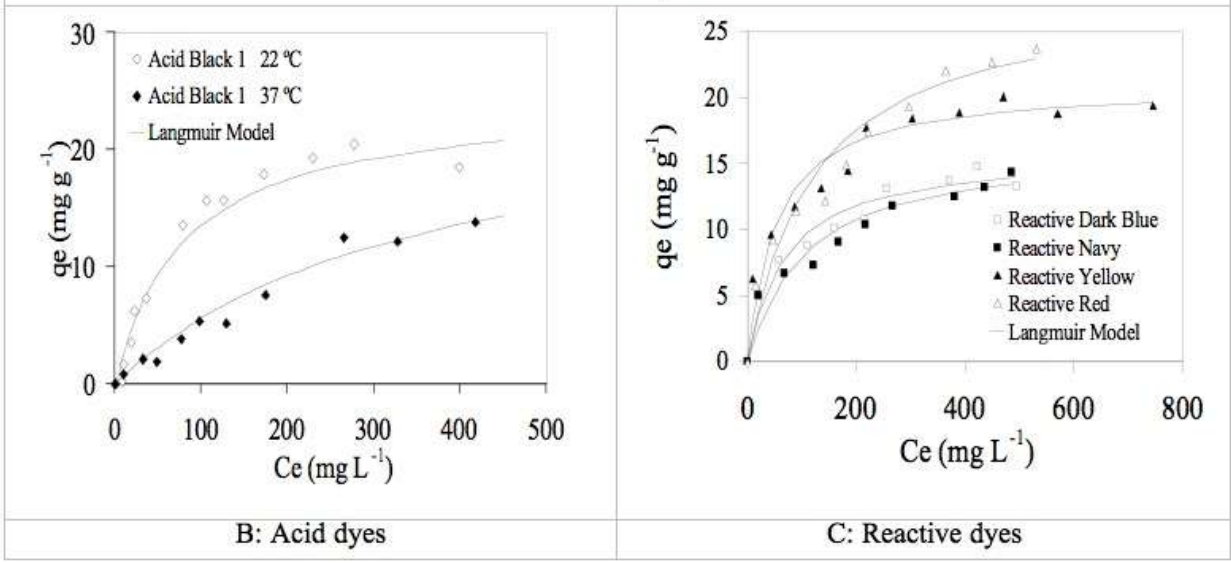

Figure 5: Dye adsorption isotherms onto peat

Figura 5: Isotermas de adsorción de colorantes en turba 
Table 4 shows the Langmuir model parameters and the maximum adsorption capacity of basic dyes which was higher than that of acid and reactive dyes. For example, $700 \mathrm{mg} \mathrm{g}^{-1}$ was obtained for Basic Violet 4 (BV4), $25 \mathrm{mg} \mathrm{g}^{-1}$ for Acid Black 1
(AB1), and $28.2 \mathrm{mg} \mathrm{g}^{-1}$ was obtained for Cibacron Red WB 150\% (RR). The greater interaction energy corresponded to basic dyes. Reactive dyes, instead, showed interaction energies up to 50 times lower than basic dyes.

Table 4: Parameter of Langmuir isotherm for the maximum adsorption capacity of basic dyes

Cuadro 4: Parámetros de la isoterma de Langmuir para la máxima capacidad de adsorción de los tintes básicos

\begin{tabular}{cccccc}
\hline \multirow{2}{*}{ Dye } & $\begin{array}{c}\text { Temperature } \\
{\left[{ }^{\circ} \mathbf{C}\right]}\end{array}$ & $\begin{array}{c}\mathbf{K}_{\mathbf{L}} \\
{\left[\mathbf{L g}^{-1}\right]}\end{array}$ & $\begin{array}{c}\mathbf{a}_{\mathbf{L}} \\
{\left[\mathbf{\mathbf { m g } ^ { - 1 }}\right]}\end{array}$ & $\begin{array}{c}\mathbf{Q}_{\mathbf{m a x}} \\
{\left[\mathbf{m g ~ g}^{-1}\right]}\end{array}$ & $\mathbf{R}^{\mathbf{2}}$ \\
\hline \multirow{2}{*}{ BB3 } & 30 & 12.92 & 0.318 & 40.6 & 0.993 \\
\cline { 2 - 6 } & 45 & 17.27 & 0.421 & 41.0 & 0.995 \\
\hline \multirow{2}{*}{ BO2 } & 30 & 28.33 & 0.306 & 92.6 & 0.997 \\
\cline { 2 - 6 } & 45 & 43.86 & 0.474 & 92.5 & 0.989 \\
\hline \multirow{2}{*}{ BB24 } & 22 & 39.35 & 0.059 & 667.0 & 0.980 \\
\cline { 2 - 6 } & 37 & 40.69 & 0.061 & 667.0 & 0.980 \\
\hline \multirow{2}{*}{ BG4 } & 22 & 18.41 & 0.035 & 526.0 & 0.980 \\
\cline { 2 - 6 } BV4 & 37 & 14.70 & 0.025 & 588.0 & 0.990 \\
\cline { 2 - 6 } & 22 & 208.5 & 0.292 & 714.0 & 0.990 \\
\hline \multirow{2}{*}{ AB1 } & 37 & 344.8 & 0.517 & 667.0 & 0.990 \\
\hline RB & 22 & 0.312 & 0.0125 & 25.0 & 0.950 \\
\hline RN & 37 & 0.073 & 0.0028 & 26.0 & 0.880 \\
\hline RY & 30 & 0.227 & 0.0143 & 15.9 & 0.978 \\
\hline RR & 30 & 0.156 & 0.0095 & 16.4 & 0.962 \\
\hline
\end{tabular}

Three bacteria strains were isolated, called 1, 2 and 3. From them, strain 1 corresponded to gram bacteria $(+)$, glucose $(+)$, lactose $(-)$, mobility $(-)$, indol test $(-)$. Gram $(+)$ and $(-)$ was detected in the remaining isolated populations.

In order to evaluate the decolourizing capacity of the strains isolated from the Magellan Peat, a screening was performed considering acid, basic and reactive dyes, as well as the Poly 478 dye used as a model dye for white rot fungi decolourization assays. Particularly, in the assays made with RO16, RR and AB1 dyes, it was observed that after first incubation over a period of $24 \mathrm{~h}$, the three isolated bacterial strains decolourized the RO16 dye, and only slight changes took place for RR and AB1. Upon $48 \mathrm{~h}$ incubation, the three strains fully decolourized RR, and strains 2 and 3 partially decolourized AB1. After $72 \mathrm{~h}$ of incubation, it was still not observed strain 
1 decolourizing $\mathrm{AB} 1$, while strains 2 and 3 decolourized it completely (Figure 6).

After $24 \mathrm{~h}$ of incubation, no apparent reaction is observed in the assay made with the Poly-R 478 dye, only gas release, a normal process related to the decomposition of the medium. This result may be a consequence of the molecular structure inherent to the dye. On the other hand, by incubating BB3 during $24 \mathrm{~h}$, no gas release was observed, therefore it is inferred that there is a probable inhibition of the microbial metabolism, caused by the medium $\mathrm{pH}$ which ranges between 3 and 4 when this dye (BB3) is added. In previous assays, it was determined that the growth of the isolated bacteria favours $\mathrm{pH}$ values of 5-6.

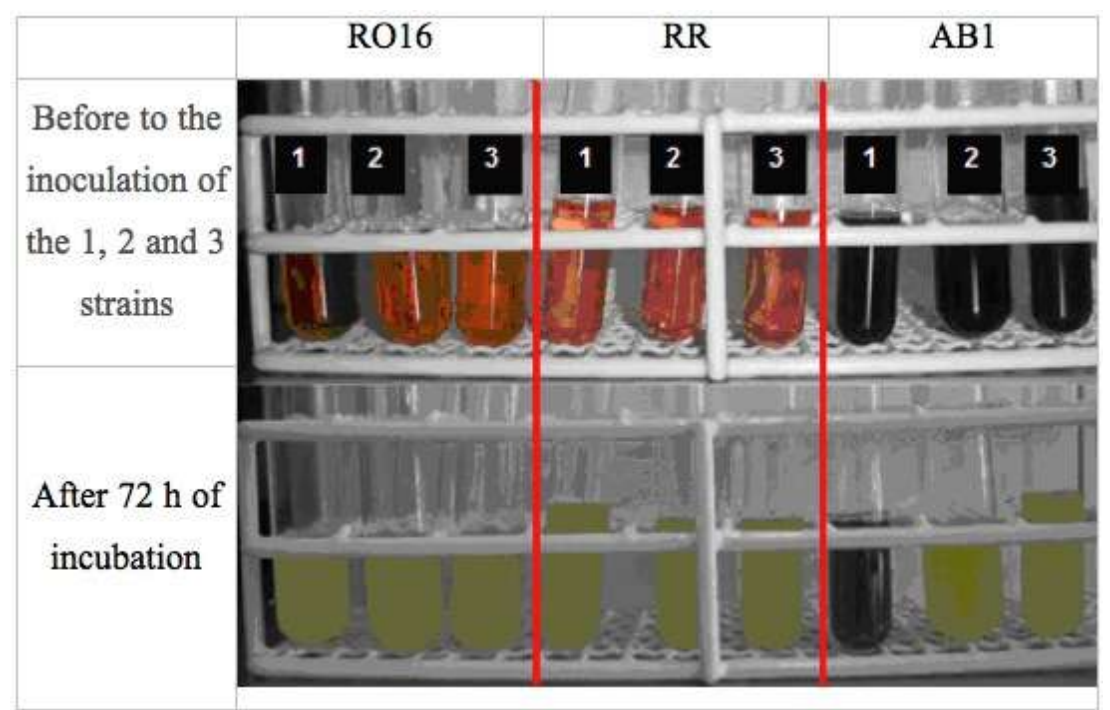

Figure 6: Decolourization assays with strain bacterial isolated from the peat.

Figura 6: Ensayos de decoloración con las cepas bacterianas aisladas de la Turba.

\section{CONCLUSIONS}

The peat is a solid material that may be classified as mesoporous, presenting a high adsorption affinity with basic dyes; therefore it may be used in a pre-treatment phase of textile effluents. These results make it compatible with the hybrid technology herein stated, since fungi such as Phanerochaete chrysosporium present a decolourization capacity for acid and reactive dyes. The bacteria isolated from the peat also showed an interesting decolourization potential of acid and reactive dyes. In conclusion, the peat may be successfully applied in the detoxification of textile effluents.

\section{ACKNOWLEDGMENT}

The authors acknowledge the financial support to FONDECYT (Project 1040089) 


\section{REFERENCES}

ABIA, A. A. AND ASUQUO, E. D. 2006 Lead (II) and nickel (II) adsorption kinetics from aqueous metal solutions using chemically modified and unmodified agricultural adsorbents, African Journal of Biotechnology 5 (16): 1475-1482.

ALLEN, S. J., WHITTEN, L. J., MURRAY, M. AND DUGGAN, O. 1997.The adsorption of pollutants by peat, lignite and activated chars. J. Chem. Tech. Biotechnol., 68: 442-452.

BENNET, I.G. 1936 Broken Coal, J. Inst. Fuel 10, 22

BROWN, P. A., GILL, S. A. AND ALLEN, S. J. 2000. Metal removal from wastewater using peat. Wat. Res. 34: 3907-3916.

CLOUTIER, J., LEDUY, A. AND RAMALHO, R. S. 1985. Peat adsorption of herbicide 2,4-D from wastewaters. The Canadian J. of Chem. Eng. 63: 250-257.

CONTRERAS, E. G., SEPÚlVEDA, L. A., PALMA, C., ANDREOLI, S. L., BASAEZ, F. 2000. Remoción de colorantes textiles básicos desde soluciones acuosas mediante adsorción en turba magallánica. Anales XVI Congreso Chileno de Ingeniería Química, Santiago, Chile, pp 10111007.

COUILLARD, D. 1994. The use of peat in wastewater treatment. Wat. Res. 28, 6: 1261-1274.

GOSSET, T., TRANCART, J. AND THEVENOT, D. 1986. Batch metal removal by peat. Wat. Res. 20: 21-26

HO, Y. S., WASE, J. AND FORSTER, C. F. 1995. Batch nickel removal from aqueous solution by sphagnum moss peat. Wat. Res. 29: 1327-1332.

HO, Y. S. AND MCKAY, G. 1998 ${ }^{\mathrm{a}}$. Sorption of dye from aqueous solution by peat. Chem. Eng. J. 70: 115-124
HO, Y. S. AND MCKAY, G. $1998^{\mathrm{b}}$.The kinetics of sorption of basic dyes from aqueous solution by sphagnum moss peat. The Canadian J. of Chem. Eng. 76: 822-827.

HO, Y. S. AND MCKAY, G. 2000. The kinetics of sorption of divalent metal ions onto sphagnum moss peat. Wat. Res. 34: 735-742.

HONG, J., EMORI, H. AND OTAKI, M. 2005. Photodecolorization of azo dyes by extracellular metabolites under fluorescent light and influence of operational parameters, Journal of Bioscience and bioengineering, 100(2): 192-196.

KNAEBEL, K.S. 1995. For your next separation on consider adsorption. Chem. Eng., 92-102.

MCKAY, G. AND ALLEN, S. J. 1980.Surface mass transfer processes using peat as an adsorbent for dyestuffs. The Canadian J. of Chem. Eng. 58: 521-526.

MCKAY, G., ALLEN, S. J., MCCONVEY, I. F. AND OTTERBURN, M. S. 1981. Transport processes in the sorption of colored ions by peat particules. $J$. of Colloid and Interface Science. 80: 323 $-339$.

MCKAY, G., GEUNDI, M. AND NASSAR, M.M. 1987. Equilibrium studies during the removal of dyestuffs from aqueous solutions using bagasse pith. Water Research, 21, 12, 1513-1520.

MCKAY, G., ALLEN, S. J. AND POOTS, V. J. 2001 Colour removal from effluent using peat-batch and fixed bed studies. I. Chem. E. Symposium Series. 59, (8): 1-13.

NAWAR, S.S. AND DOMA, H.S. 1989. Removal of dyes from effluents using low cost agricultural by products. The Science of the Total Environment, 79: 271-279. 
NIGAM, P. ARMOU, G., BANAT, I. M., SINGH D. AND MARCHANT R. 2000. Physical removal of textile dyes from effluents and solid-state fermentation of dye-adsorbed agricultural residues, Bioresource Technology, 72 (3): 219-226. OJEDA, M. L., AGUILA, C. AND LÓPEZ, L. 1998. Estudio de la capacidad de adsorción de metales en la turba magallánica. Anales XII Congreso Chileno de Ingeniería Química, Antofagasta, pp 108-115.

OPELT, K., CHOBOT, V., HADACEK, F., SCHÖNMANN, S., EBERL, L. AND BERG, G.2007 Investigations of the structure and function of bacterial communities associated with Sphagnum mosses Environ. Microbiol. 9(11): 2795-2809
SANKAR, M., SEKARAN, G., SADULLA, S. AND RAMASAMI, T. 1999. Removal of diazo and triphenylmethane dyes from aqueous solutions through and adsorption process. Chem. Technol Biotechnol. 74: 337-344.

VIJAYKUMAR M.H., VAISHAMPAYAN P. A., SHOUCHE Y. S. AND KAREGOUDAR T.B. 2007 Decolourization of naphthalenecontaining sulfonated azo dyes by Kerstersia sp. strain VKY1, Enzyme Microbiol. Technol. 40 (2): 204-211. 